\title{
The efficacy of vitamin E-polyethylene glycol complex on growth performance, chicken meat quality and immunity in broilers*
}

\author{
B.J. Chae ${ }^{1}$, J.D. Lohakare ${ }^{1}$, J.Y. Choi ${ }^{1}$, K.N. Han ${ }^{1}$, J.S. Yong ${ }^{1}$, \\ H.K. Won ${ }^{1}$, Y.H. Park ${ }^{2}$ and T.-W. Hahn ${ }^{1,3}$ \\ ${ }^{1}$ College of Animal Resources, Kangwon National University \\ Chunchon 200-701, Korea \\ ${ }^{2}$ College of Veterinary Medicine, Seoul National University \\ Seoul 151-742, Korea
}

(Received 30 June 2004; revised version 26 July 2004; accepted 31 January 2005)

\begin{abstract}
The experiment was conducted to evaluate the efficacy of vitamin E-polyethylene glycol complex (VE-PEG) in commercial broilers. Three hundred and thirty Ross broiler chickens, 4 days old, were randomly distributed and allotted to 5 dietary treatments for six weeks. The vitamin $\mathrm{E}$ (VE) levels in the 5 dietary treatments were, $\mathrm{mg} / \mathrm{kg}: 1.0$ (negative control), 2. 200 $\alpha$-tocopheryl acetate, 3. 10 VE-PEG, 4. 20 VE-PEG, and 5. 50 VE-PEG. Overall study showed that supplementation of VE has improved the weight gain at $20 \mathrm{mg} / \mathrm{kg}, 50 \mathrm{mg} / \mathrm{kg}$ VE-PEG and 200 $\mathrm{mg} / \mathrm{kg}$ VE levels, over those fed 0 or $10 \mathrm{mg} / \mathrm{kg}$ VE-PEG, but the feed intake and feed conversion efficiency remained unaffected. Bone resistance was improved in all VE supplemented diets than control. Significantly $(\mathrm{P}<0.05)$ higher phosphorus content in bone was recorded at $50 \mathrm{mg} / \mathrm{kg} \mathrm{VE}-$ PEG fed group. The carcass traits like dressing percentage, breast meat, abdominal fat and the meat colour did not differ significantly due to treatments. The serum levels of VE and its concentration in the muscle showed positive linear correlation with the levels supplemented. The thiobarbituric acid reactive substances (TBARS) $(\mathrm{mg} / \mathrm{kg}$ ) levels in meat also suggested that supplemental VE has a protective role in rancidity. The cytotoxic T cells (CD8) and B-lymphocyte cells were higher in 50 $\mathrm{mg} / \mathrm{kg}$ VE-PEG fed group. VE did not affect the infectious bronchitiserase and Newcastle disease antibody titres. Overall, it can be concluded that VE at higher levels in both $\alpha$-tocopheryl acetate and VE-PEG form was found beneficial for the growth, immunity and increased the chicken meat quality.
\end{abstract}

KEY WORDS: vitamin E, growth, broiler, polyethylene glycol, immunity, bone

\footnotetext{
${ }^{*}$ Supported by LG Life Sciences Ltd., Seoul, Korea

${ }^{3}$ Corresponding author: e-mail: twhahn@kangwon.ac.kr
} 


\section{INTRODUCTION}

The broilers are in continuous stress due to faster growth rate, pathogens and the ever-changing environmental conditions in the broiler houses (McCorkle and Glick, 1980). Lots of research work showed that a higher dietary allowance of vitamin E (VE) has beneficial effects on chickens (Mazija et al., 1992; McIlroy et al., 1993; Haq et al., 1996) such as enhanced immune competence, especially under commercial production conditions. It is well-established fact that the supplementation of VE has some protective role under such stressing conditions. It has also been proved that VE has a role in growth, immunity and in the protection of biological systems against oxidative damage in live animals as well as in the meat and meat products (Tengerdy et al., 1984; Jacobsen et al., 1995). These antioxidant functions are important because the oxidation of muscle lipids after slaughter can adversely affects the flavour and nutritive value of fresh, frozen and cooked meat and meat products (Morrissey et al., 1998). Moreover, VE in the form of tocopheryl acetate is more prone to oxidation due to temperature, moisture and humidity, which all cumulatively work to reduce the vitamin potency. Hence antioxidants such as ethoxyquin are purposefully added in diets to protect the formation of peroxides in feeds (Scott and Stoewsand, 1961) and may decrease the amount of alpha-tocopheryl quinone in tissues (Dudin and Dvinskaya, 1984). VE-polyethylene glycol complex (VE-PEG) is known to be more stable than any other VE sources during storage at the room temperature. This VE-PEG compound was proven to show higher bioavailability and growth promotant effects. Also supplementing the diet of finishing pigs with $90 \mathrm{mg} / \mathrm{kg}$ of this compound improved growth performance compared to controls (LG Chemical's Report, 2000). Hence the present study was conducted to investigate the effect of different levels of VE-PEG on growth performance, nutrient digestibility, meat quality and immunity in broilers.

\section{MATERIAL AND METHODS}

For a six-week feeding trial, a total of 330 broiler chickens (Ross, 4-day old, average $57.0 \pm 2.1 \mathrm{~g}$ body weight) were allotted to five dietary treatments with three replicates in each group, in a room with rice hull litter material. The room temperature was not controlled except during the first week $\left(22-30^{\circ} \mathrm{C}\right)$ because it was summer season (June-August). The pen size was $1.5 \mathrm{~m} \times 1.2 \mathrm{~m}$. The day-old chickens were reared with a commercial starter diet for three days followed by respective experimental diets. Chickens had ad libitum access to diets and water. Uniform management and vaccination schedule was followed for all the birds. 
Basal diets (mash type) were formulated to contain 22.0 and $20.3 \%$ crude protein for starter (0-3 week) and finisher (4-6 week), respectively (Table 1). The dietary treatments were, $\mathrm{mg} / \mathrm{kg}: 1.0$ (negative), 2. $200 \alpha$-tocopheryl acetate, 3.10 VE-PEG, 4. 20 VE-PEG, and 5. 50 VE-PEG.

TABLE 1

Chemical composition of basal diets

\begin{tabular}{|c|c|c|}
\hline Indices & Starter $(0-3 \mathrm{wk})$ & Finisher (4-6 wk) \\
\hline \multicolumn{3}{|l|}{ Ingredients, \% } \\
\hline maize & 56.06 & 59.90 \\
\hline soyabean meal $(44 \% \mathrm{CP})$ & 22.44 & 20.76 \\
\hline maize gluten meal & 7.00 & 8.00 \\
\hline fish meal & 6.16 & 3.00 \\
\hline animal fat & 6.00 & 5.70 \\
\hline tricalcium phosphate & 0.92 & 1.12 \\
\hline limestone & 0.59 & 0.87 \\
\hline vitamin $_{\text {premix }}{ }^{1}$ & 0.10 & 0.10 \\
\hline trace mineral premix ${ }^{2}$ & 0.20 & 0.20 \\
\hline salt & 0.25 & 0.25 \\
\hline L-lysine $\mathrm{HCl}$ & - & 0.03 \\
\hline DL-methionine $(50 \%)$ & 0.20 & - \\
\hline choline chloride $(25 \%)$ & 0.08 & 0.07 \\
\hline \multicolumn{3}{|c|}{ Chemical composition calculated, \% } \\
\hline $\mathrm{ME}, \mathrm{kcal} / \mathrm{kg}$ & 3200 & 3200 \\
\hline crude protein & 22.0 & 20.3 \\
\hline $\mathrm{Ca}$ & 0.90 & 0.90 \\
\hline available $\mathrm{P}$ & 0.40 & 0.35 \\
\hline lysine & 1.14 & 1.00 \\
\hline methionine & 0.53 & 0.40 \\
\hline methionine + cystine & 0.90 & 0.75 \\
\hline
\end{tabular}

For a digestibility trial, thirty chickens ( 6 birds per treatment) were allocated in individual cages to collect faecal samples. Starter and finisher diets containing $0.25 \%$ chromic oxide as an indigestible marker were given to chickens at the age of 15 and 35 days, respectively. Faecal samples of each bird were collected on the $4^{\text {th }}$ day after feeding the respective marked diets. Faeces were dried in an air forced drying oven at $60^{\circ} \mathrm{C}$ for 3 days and then ground and stored for chemical analysis. Body weight gain and feed intake were recorded at weekly intervals at the end of each week. Proximate analysis of the samples was made according to the methods 
of AOAC (1990). Gross energy was measured with an adiabetic bomb calorimeter (Model 1241, Parr Instrument Co., Molin, IL), vitamin E with HPLC (Waters, Model 486, USA) and chromium with spectrometer (Jasco Co., Model V-550, Japan).

At the end of the experiment, nine chickens per treatment were sacrificed. Blood samples were taken to analyse VE contents. Chicken meat colour of breast meat was measured with a colour difference meter (Yasuda Seiko Co., CR 310, Minolta, Japan) and compared with standard colour values. Carcass traits like dressing percentage, breast meat and abdominal fat were also measured. Bone mineralization was studied in terms of bone breaking strength of tibia, ash content and calcium and phosphorus content. For this both the tibia were freed of soft tissue. The dried $\left(100^{\circ} \mathrm{C} / 3 \mathrm{~h}\right)$ bone samples were defattened in petroleum ether for $48 \mathrm{~h}$. The right tibia of each bird was used to determine the breaking strength (EZ Test, Shimadzu, Japan). The ground breast meat was stored at $1^{\circ} \mathrm{C}$ for 10 days after slaughter to determine thiobarbituric acid reactive substances (TBARS) as $\mathrm{mg}$ of malonaldehyde $(\mathrm{mg} / \mathrm{kg})$ by the method of Sinnhubber and Yu (1977). The VE content in the breast meat was also measured by HPLC.

In order to study the effect of dietary VE supplementation on lymphocyte subpopulation, blood was collected from wing vein of four chickens in each group after 27 days of feeding. To analyse the avian leukocyte subpopulation, cells were prepared by the method according to the Davis et al. (1990) with minor modification. The peripheral blood lymphocytes were isolated from the buffy coat layer of the centrifuged blood using Hypaque Ficoll (Histopaque 1.803, Sigma, USA), washed three times and resuspended at $1 \times 10^{7}$ cells $/ \mathrm{ml}$ in a FB-PBS $(11.3$ $\mathrm{mM}$ sodium phosphate, $3.8 \mathrm{mM}$ potassium phosphate, $125 \mathrm{mM}$ sodium chloride, $10 \mathrm{mM}$ EDTA, $0.1 \%$ sodium azide, $10 \%$ acid citrate dextrose, $2 \%$ globulin free horse serum). A $100 \mu 1$ aliquot of cell suspension was added to 96 well plate and mixed with $15 \mu 1$ of each mouse-anti-chicken monoclonal antibodies (mAb) specific for various leucocyte differentiation antigen markers. The panel of $\mathrm{mAb}$ included mAb specific for CD4 (T helper cell), CD8a (cytotoxic T cells), TCR-I cell, TCR-II and B-lymphocyte. After incubation and washing, the cell suspension was incubated with $100 \mu \mathrm{l}$ of $1 / 200$ diluted fluorescein isothiocyanate (FITC)conjugated goat anti-mouse $\mathrm{IgG}+\operatorname{IgM}$ antibody (Caltag Lab, USA). Labeled lymphocytes were counted and analysed with FACs Calibur and CellQuest program (Becton Dickinson, USA).

Effect of supplementation of VE on the antibody response to Newcastle disease (ND) and infectious bronchitis (IB) vaccine was also studied. After 15 days of feeding, 6 chickens per group were inoculated intramuscularly with ND+IB inactivated oil-emulsion vaccine. Blood was collected at 14 and 28 days after vaccination. Serum was isolated and stored at $-20^{\circ} \mathrm{C}$ until analysed. Antibody titers to ND or IB were determined by an enzyme-linked immunosorbent assay 
(ELISA) kit (Jeil-Bio Co., Korea) according to manufacturer's instruction. The antibody titer was calculated from the $\mathrm{S} / \mathrm{P}$ ratio and $\log$ titer following manufacturer's directions. The data was analysed using the General Linear Model (GLM) procedure of SAS (1985) following the completely randomized block design.

\section{RESULTS}

The supplemental effect of VE on the growth performance of broilers was recorded at $21^{\text {st }}$ and $42^{\text {nd }}$ day of age, and increasing trend was noticed as the levels of $\mathrm{VE}$ in the diets was increased (Table 2). Linear significant $(\mathrm{P}<0.05)$ increasing trend was observed at all the phases of measurement. Feed intake and feed to gain ratio was not affected by the VE levels during all periods, although there was a trend towards increasing weight gain as dietary VE was increased.

TABLE 2

The effect of dietary vitamin $\mathrm{E}$ on growth performance in broilers

\begin{tabular}{|c|c|c|c|c|c|c|c|}
\hline \multirow{2}{*}{$\begin{array}{l}\text { Treatments } \\
\mathrm{mg} / \mathrm{kg}\end{array}$} & \multicolumn{2}{|c|}{ Vitamin E } & \multicolumn{3}{|c|}{ Polyethylene glycol-E } & \multirow{2}{*}{$\mathrm{SE}^{1}$} & \multirow{2}{*}{$\frac{\text { P-value }}{\text { Linear }}$} \\
\hline & 0 & 200 & 10 & 20 & 50 & & \\
\hline \multicolumn{8}{|l|}{ Starter (0-3 wk) } \\
\hline weight gain, $g$ & $466^{c}$ & $559^{\mathrm{a}}$ & $517^{\mathrm{b}}$ & $529^{b}$ & $556^{\mathrm{a}}$ & 36.5 & 0.00 \\
\hline feed intake, $g$ & 985 & 1051 & 980 & 1017 & 1074 & 78.8 & $\mathrm{NS}^{2}$ \\
\hline feed:gain & 2.11 & 1.88 & 1.90 & 1.92 & 1.93 & 0.16 & NS \\
\hline \multicolumn{8}{|l|}{ Finisher (4-6 wk) } \\
\hline weight gain, $g$ & $919^{\mathrm{b}}$ & $1054^{\mathrm{a}}$ & $991^{\mathrm{ab}}$ & $1006^{\mathrm{a}}$ & $1018^{\mathrm{a}}$ & 75.8 & 0.03 \\
\hline feed intake, $g$ & 2469 & 2691 & 2317 & 2495 & 2536 & 443 & NS \\
\hline feed:gain & 2.67 & 2.56 & 2.33 & 2.48 & 2.51 & 0.43 & NS \\
\hline \multicolumn{8}{|l|}{ Overall (0-6 wk) } \\
\hline weight gain, g & $1386^{\mathrm{b}}$ & $1614^{\mathrm{a}}$ & $1509^{\mathrm{ab}}$ & $1536^{\mathrm{a}}$ & $1575^{\mathrm{a}}$ & 99.2 & 0.00 \\
\hline feed intake, $g$ & 3454 & 3668 & 3300 & 3487 & 3512 & 437 & NS \\
\hline feed:gain & 2.49 & 2.28 & 2.19 & 2.27 & 2.22 & 0.27 & NS \\
\hline Mortality, \% & 9.09 & 0.00 & 4.55 & 3.03 & 1.52 & & \\
\hline
\end{tabular}

The apparent nutrient digestibility studies (Table 3) of experimental feeds denote a linear significant $(\mathrm{P}<0.05)$ higher digestibility of gross energy at 200 $\mathrm{mg} / \mathrm{kg}$ VE group followed by $50 \mathrm{mg} / \mathrm{kg}$ VE-PEG level which had a positive effect on growth rate. Digestibility studies at both intervals with respect to ether extract did not show any significant effect due to dietary treatments. 
TABLE 3

The effect of supplemental vitamin $\mathrm{E}$ on nutrient digestibility in broilers

\begin{tabular}{|c|c|c|c|c|c|c|c|}
\hline \multirow{2}{*}{$\begin{array}{l}\text { Treatments } \\
\mathrm{mg} / \mathrm{kg}\end{array}$} & \multicolumn{2}{|c|}{ Vitamin E } & \multicolumn{3}{|c|}{ Polyethylene glycol -E } & \multirow{2}{*}{$\mathrm{SE}^{1}$} & \multirow{2}{*}{$\begin{array}{l}\text { P-value } \\
\text { Linear }\end{array}$} \\
\hline & 0 & 200 & 10 & 20 & 50 & & \\
\hline \multicolumn{8}{|l|}{ Starter (Day 15) } \\
\hline gross energy & $69.8^{\mathrm{d}}$ & $74.6^{\mathrm{a}}$ & $71.3^{\mathrm{c}}$ & $72.8^{\mathrm{b}}$ & $74.0^{\mathrm{a}}$ & 1.79 & 0.00 \\
\hline crude protein & $71.3^{\mathrm{b}}$ & $76.8^{\mathrm{a}}$ & $72.6^{b}$ & $73.5^{\mathrm{ab}}$ & $76.5^{\mathrm{a}}$ & 3.07 & 0.02 \\
\hline ether extract & 72.9 & 75.3 & 73.8 & 73.8 & 74.5 & 1.62 & $\mathrm{NS}^{2}$ \\
\hline \multicolumn{8}{|l|}{ Finisher (Day 35) } \\
\hline gross energy & $70.8^{\mathrm{d}}$ & $74.4^{\mathrm{a}}$ & $71.9^{\mathrm{c}}$ & $72.4^{\mathrm{bc}}$ & $72.9^{\mathrm{b}}$ & 1.25 & 0.00 \\
\hline crude protein & 70.7 & 74.8 & 72.4 & 72.6 & 73.5 & 8.50 & NS \\
\hline ether extract & 70.0 & 72.7 & 71.6 & 71.9 & 72.5 & 8.64 & NS \\
\hline
\end{tabular}

abcd values with different superscripts in the same row differ significantly $(\mathrm{P}<0.05)$

${ }^{1}$ pooled standard errors, $\mathrm{n}=6$ birds/treatment

2 not significant

The tibia breaking strength was significantly $(\mathrm{P}<0.05)$ increased linearly by increasing the VE levels in the diet (Table 4). Bone resistance was found lowest where no VE was supplemented. The composition of the bone was comparable with respect to crude ash and calcium content.

TABLE 4

The effect of supplemental vitamin $\mathrm{E}$ on resistance and chemical composition of tibia bone

\begin{tabular}{|c|c|c|c|c|c|c|c|}
\hline \multirow{2}{*}{$\begin{array}{l}\text { Treatments } \\
\mathrm{mg} / \mathrm{kg}\end{array}$} & \multicolumn{2}{|c|}{ Vitamin E } & \multicolumn{3}{|c|}{ Polyethylene glycol -E } & \multirow{2}{*}{$\mathrm{SE}^{1}$} & \multirow{2}{*}{$\frac{\text { P-value }}{\text { Linear }}$} \\
\hline & 0 & 200 & 10 & 20 & 50 & & \\
\hline Dry matter & $80.2^{\mathrm{ab}}$ & $76.4^{b}$ & $83.8^{\mathrm{a}}$ & $77.6^{\mathrm{b}}$ & $75.4^{\mathrm{b}}$ & 3.93 & 0.03 \\
\hline Crude ash & 52.2 & 57.5 & 52.3 & 52.6 & 57.8 & 3.92 & $\mathrm{NS}^{2}$ \\
\hline Calcium & 14.2 & 16.4 & 15.6 & 16.2 & 16.6 & 1.54 & NS \\
\hline Phosphorus & $6.45^{\mathrm{b}}$ & $7.40^{\mathrm{ab}}$ & $6.70^{\mathrm{b}}$ & $7.26^{\mathrm{ab}}$ & $8.35^{\mathrm{a}}$ & 0.83 & 0.00 \\
\hline Bone resistance, $\mathrm{kg}$ & $20.3^{\mathrm{c}}$ & $28.6^{\mathrm{a}}$ & $24.7^{\mathrm{b}}$ & $25.4^{\mathrm{ab}}$ & $27.6^{\mathrm{a}}$ & 3.80 & 0.02 \\
\hline
\end{tabular}

abc values with different superscripts in the same row differ significantly $(\mathrm{P}<0.05)$

${ }^{1}$ pooled standard errors, $\mathrm{n}=9$ birds/treatment

${ }^{2}$ not significant

The carcass traits studies revealed no effect of VE on dressing percentage, breast meat and abdominal fat content (Table 5). The meat colour when compared with the standard values also did not show significant changes when compared among the treatments.

VE content in serum and muscles revealed significantly $(\mathrm{P}<0.05)$ higher levels as the level of supplementation increased in the diet (Table 6). A significant positive trend was recorded between the levels of VE supplemented in the diets and its levels in serum and muscle. TBARS values were significantly $(\mathrm{P}>0.05)$ lower in the VE supplemented diets studied after 5 and 10 days of storage. The VE supplemented at $50 \mathrm{mg} / \mathrm{kg}$ VE-PEG group was at par with that of $200 \mathrm{mg} / \mathrm{kg}$ VE levels with respect to TBARS value after storage studies at both intervals (5 and 10 days). 
TABLE 5

The effect of supplemental vitamin $\mathrm{E}$ on carcass traits and meat colour in broilers

\begin{tabular}{|c|c|c|c|c|c|c|c|}
\hline \multirow{2}{*}{$\begin{array}{l}\text { Treatments } \\
\mathrm{mg} / \mathrm{kg}\end{array}$} & \multicolumn{2}{|c|}{ Vitamin E } & \multicolumn{3}{|c|}{ Polyethylene glycol-E } & \multirow{2}{*}{$\mathrm{SE}^{1}$} & \multirow{2}{*}{$\frac{\text { P-value }}{\text { Linear }}$} \\
\hline & 0 & 200 & 10 & 20 & 50 & & \\
\hline \multicolumn{8}{|l|}{ Carcass traits, $\%$} \\
\hline dressing percentage & 73.9 & 76.0 & 73.2 & 75.3 & 73.1 & 3.00 & $\mathrm{NS}^{2}$ \\
\hline breast meat & 11.0 & 12.9 & 11.2 & 13.1 & 11.6 & 1.53 & NS \\
\hline abdominal fat & 2.45 & 2.03 & 2.34 & 2.92 & 2.35 & 0.44 & NS \\
\hline \multicolumn{8}{|l|}{ Meat colour } \\
\hline $\mathrm{L}$ & 58.8 & 60.7 & 59.1 & 58.7 & 56.0 & 2.09 & NS \\
\hline $\mathrm{a}$ & 9.95 & 10.4 & 8.80 & 9.24 & 11.5 & 1.13 & NS \\
\hline $\mathrm{b}$ & 7.32 & 9.72 & 10.1 & 7.71 & 6.58 & 2.07 & NS \\
\hline
\end{tabular}

${ }^{1}$ pooled standard errors, $\mathrm{n}=9$ birds/treatment

2 not significant

TABLE 6

The effect of supplemental vitamin $\mathrm{E}$ on serum and muscle vitamin $\mathrm{E}$ content, and TBARS level in breast muscle

\begin{tabular}{|c|c|c|c|c|c|c|c|}
\hline \multirow{2}{*}{$\begin{array}{l}\text { Treatments } \\
\mathrm{mg} / \mathrm{kg}\end{array}$} & \multicolumn{2}{|c|}{ Vitamin E } & \multicolumn{3}{|c|}{ Polyethylene glycol -E } & \multirow{2}{*}{$\mathrm{SE}^{1}$} & \multirow{2}{*}{$\begin{array}{r}\text { P-value } \\
\text { Linear } \\
\end{array}$} \\
\hline & 0 & 200 & 10 & 20 & 50 & & \\
\hline Serum, ppm & $1.41^{\mathrm{e}}$ & $22.0^{\mathrm{a}}$ & $5.55^{\mathrm{d}}$ & $8.57^{\mathrm{c}}$ & $16.7^{\mathrm{b}}$ & 7.79 & 0.00 \\
\hline Muscle, ppm & $0.55^{\mathrm{e}}$ & $15.6^{\mathrm{a}}$ & $2.43^{\mathrm{d}}$ & $4.95^{\mathrm{c}}$ & $13.6^{\mathrm{b}}$ & 6.26 & 0.00 \\
\hline $\begin{array}{l}\text { TBARS, } \mathrm{mg} / \mathrm{k} \\
\text { day } 0\end{array}$ & 0.33 & 0.35 & 0.32 & 0.29 & 0.30 & 0.02 & $\mathrm{NS}^{2}$ \\
\hline day 5 & $1.63^{\mathrm{a}}$ & $1.60^{\mathrm{c}}$ & $1.13^{\mathrm{b}}$ & $0.83^{b}$ & $0.69^{c}$ & 0.42 & 0.00 \\
\hline day 10 & $2.82^{\mathrm{a}}$ & $1.42^{\mathrm{c}}$ & $1.82^{\mathrm{b}}$ & $1.63^{\mathrm{bc}}$ & $1.51^{\mathrm{c}}$ & 0.54 & 0.00 \\
\hline
\end{tabular}

The CD8 and $\mathrm{B}$ cells were significantly ( $\mathrm{P}=0.005$ and $\mathrm{P}=0.03$, respectively) higher in $50 \mathrm{mg} / \mathrm{kg}$ VE-PEG group as compared to control (Table 7). The CD4, TCR-I and TCR-II cells were not affected by VE supplementation.

TABLE 7

The effect of supplemental vitamin E on lymphocyte sub-population

\begin{tabular}{|c|c|c|c|c|c|c|c|}
\hline \multirow{2}{*}{$\begin{array}{l}\text { Treatments } \\
\mathrm{mg} / \mathrm{kg}\end{array}$} & \multicolumn{2}{|c|}{ Vitamin E } & \multicolumn{3}{|c|}{ Polyethylene glycol -E } & \multirow{2}{*}{$\mathrm{SE}^{1}$} & \multirow{2}{*}{$\frac{\text { P-value }}{\text { Linear }}$} \\
\hline & 0 & 200 & 10 & 20 & 50 & & \\
\hline \multicolumn{8}{|c|}{ Lymphocytic cells } \\
\hline CD4 & 14.0 & 23.0 & 37.1 & 27.3 & 31.6 & 2.72 & 0.05 \\
\hline CD8 & $5.03^{\mathrm{b}}$ & $5.88^{\mathrm{b}}$ & $15.0^{\mathrm{a}}$ & $10.1^{\mathrm{ab}}$ & $15.8^{\mathrm{a}}$ & 1.32 & 0.00 \\
\hline TCR-I & 7.60 & 8.50 & 9.55 & 13.8 & 13.7 & 1.08 & $\mathrm{NS}^{2}$ \\
\hline TCR-II & 12.5 & 8.23 & 22.0 & 35.1 & 16.6 & 5.04 & NS \\
\hline B-cells & $2.95^{\mathrm{b}}$ & $3.40^{\mathrm{b}}$ & $3.33^{\mathrm{b}}$ & $4.08^{\mathrm{b}}$ & $7.65^{\mathrm{a}}$ & 0.56 & 0.03 \\
\hline
\end{tabular}

${ }^{a b}$ values with different superscripts in the same row differ significantly $(\mathrm{P}<0.05)$

${ }^{1}$ pooled standard error, $\mathrm{n}=4$ birds/treatment

${ }^{2}$ not significant 
The ELISA titers to IB were higher numerically at $14^{\text {th }}$ day of measurement at $50 \mathrm{mg} / \mathrm{kg}$ VE-PEG fed group and the lowest in $10 \mathrm{mg} / \mathrm{kg}$ supplemented group, but at $28^{\text {th }}$ day, the titer was lowest in control group as compared to its supplemented counterparts. The ND titers were not significantly influenced at $14^{\text {th }}$ or $28^{\text {th }}$ day of measurement by VE supplementation though numerically higher values were noted in supplemented group than non-supplemented one at 28th day. It is worthwhile to note here that antibody titer change from $14^{\text {th }}$ day to $28^{\text {th }}$ day.

TABLE 8

The effect of supplemental vitamin E on IB and ND antibody titers

\begin{tabular}{|c|c|c|c|c|c|c|c|}
\hline \multirow{2}{*}{$\begin{array}{l}\text { Treatments } \\
\mathrm{mg} / \mathrm{kg}\end{array}$} & \multicolumn{2}{|c|}{ Vitamin E } & \multicolumn{3}{|c|}{ Polyethylene glycol -E } & \multirow{2}{*}{$\mathrm{SE}^{1}$} & \multirow{2}{*}{$\begin{array}{r}\text { P-value } \\
\text { Linear }\end{array}$} \\
\hline & 0 & 200 & 10 & 20 & 50 & & \\
\hline \multicolumn{8}{|l|}{ IB titers } \\
\hline $14^{\text {th }}$ day & 2029 & 2291 & 1680 & 2282 & 3188 & 372 & $\mathrm{NS}^{2}$ \\
\hline $28^{\text {th }}$ day & 944 & 1854 & 2232 & 2077 & 1318 & 226 & NS \\
\hline \multicolumn{8}{|l|}{ ND titers } \\
\hline $14^{\text {th }}$ day & 293 & 169 & 307 & 269 & 889 & 142 & NS \\
\hline $28^{\text {th }}$ day & 870 & 2943 & 2809 & 4163 & 3347 & 455 & NS \\
\hline
\end{tabular}

${ }^{1}$ pooled standard error, $\mathrm{n}=6$ birds/treatment

${ }^{2}$ not significant

\section{DISCUSSION}

The weight gain was higher in supplemented diets than non-supplemented one at all levels of measurement in our study. But the report of not significantly improving the weight gain even after supplementing VE up to $180 \mathrm{mg} / \mathrm{kg}$ diets was recorded by Sheehy et al. (1991). Our results paralleled with the findings of Frigg et al. (1990) in broilers fed a diet containing $200 \mathrm{mg}$ VE/kg which showed the highest mean body weight and the best feed conversion, but the effects were non significant. Guo et al. (2001) recorded that supplementation of VE at 0, 5, 10, $50,100 \mathrm{mg} / \mathrm{kg}$ for $0-3$ weeks broiler chickens did not influence the feed intake, but tended to improve growth and feed utilization, however there was no significant correlation between performance and dietary VE levels supplemented. They found supplementation of VE improved growth and feed utilization of birds during 0-3 weeks of age but the performance from 0-6 weeks age were not influenced. More prominent and significant changes in body weight during starter phase in our study may be due to insufficient immune status of the bird during early age and the role of vitamin $\mathrm{E}$ in improving immunity. The benefits in performance from high dietary concentration of VE would only be observed in the presence of free radical attack on the immune system (Franchini et al., 1988; Rice and Kennedy, 
1988). The summer and growth stress must have triggered increased production of lipid free radicals and hence better growth was found in supplemented group. Severe growth depression and reduced feed to gain ratio was occurred where no VE was supplemented due to decrease in feed intake. No significant effect on feed intake and feed conversion ratio was found due to dietary treatments. Our results contradicts the findings of Soto-salanova et al. (1993) where $100 \mathrm{IU}$ of $D$ - $\alpha$-tocopheryl polyethylene glycol succinate had no effect on growth rate and feed efficiency of 21 days old poults.

The digestibility of gross energy was significantly reduced where no VE was supplemented which culminated into lower weight gain in this group. The gross energy digestibility was also reported higher in 10 and $20 \mathrm{mg} / \mathrm{kg}$ VE supplemented diets, when compared to non-supplemented group, in our earlier studies conducted during starter and finisher phase in broilers (Lohakare et al., 2004). The higher levels of VE even in PEG form did not have much impact on the digestibilities of nutrients during finisher phase.

The tibia breaking strength was significantly $(\mathrm{P}<0.05)$ increased linearly by increasing the VE levels in the diet. This gives the idea of the possible role of VE in strengthening of bone. Fewer studies have been conducted with respect to supplementation of $\mathrm{VE}$ on bone strength and composition. Higher $(\mathrm{P}=0.001)$ phosphorus content and maximum numerical values of crude ash, and calcium were recorded in VE supplemented diets at higher levels and this may be the reason of increasing the bone strength in these groups due to increased bone mineralization. The studies by $\mathrm{Xu}$ et al. (1994) that supplemental tocopherols enhanced bone formation of chickens showed the possibility of this vitamin on bone metabolism. The calcium content in left femur bone of rat was increased by supplementing tocopherols at $90 \mathrm{mg} / \mathrm{kg}$ body weight/day was studied by Norazlina et al. (1999), and they postulated that tocopherol supplementation induced calcium deposition in bones but it inhibited deposition of other minerals that also contribute to bone mineral density such as magnesium, phosphate and zinc. The reason of increasing phosphorus content in the VE supplemented group is unclear to us hence further studies are recommended in this area.

The carcass traits studies revealed no effect of VE on dressing percentage, breast meat and abdominal fat content. In chicken meat colours, 'a' value for redness was increased non-significantly with the increasing levels of VE in PEG form and it was still higher than the $200 \mathrm{mg} / \mathrm{kg}$ when compared with $50 \mathrm{mg} / \mathrm{kg}$ VE-PEG complex which was significant finding of the study. The ' $b$ ' value for brownness was decreased numerically which means the muscle oxymyoglobin oxidized in the presence of oxidizing lipids and the undesirable brown discolouration results. Thus the texture of meat was improved by VE supplementation at $50 \mathrm{mg} / \mathrm{kg}$ VE-PEG group but not by $200 \mathrm{mg} / \mathrm{kg}$ level as 
$\alpha$-tocopheryl acetate. The colour stability of meat could be attributed to a VE mediated reduction in lipid and myoglobin oxidation following supplementation of VE in the PEG-complex form.

The serum levels of VE was in agreement with the levels of VE supplemented in diets and same was the case with its levels in breast muscles. A significant positive trend was recorded between the levels of VE supplemented in the diets and its levels in serum and muscle. The TBARS values are a good index reflecting the degree of oxidation. The VE supplemented at $50 \mathrm{mg} / \mathrm{kg}$ VE-PEG group was at par with that of $200 \mathrm{mg} / \mathrm{kg}$ VE levels with respect to TBARS value after storage studies at both intervals ( 5 and 10 days). This suggest that VE improved the lipid stability of meat during storage and was in agreement with that of reported by Guo et al. (2001). There exists an inverse correlation between the muscle TBARS values and $\alpha$-tocopherol content in the muscle. The peroxidation levels were low in the chickens fed $200 \mathrm{mg} / \mathrm{kg}$ of VE. This showed that the retention time of VE in the PEG-complex form in muscle was equivalent to that of $200 \mathrm{mg} / \mathrm{kg}$ levels as $\alpha$-tocopheryl acetate. The antioxidant function of VE persists after slaughter and delayed the onset of oxidation reactions in meat and meat products (DeVore et al. 1983). This might be the reason of improving the texture and keeping quality of meat as was also noticed by observing the VE content in the muscles. This revealed the positive impact of VE in PEG-form in muscles as it was prevented from oxidative damage during its circulation. There also exists possibility that supplementation of VE at higher levels must have benefited birds from stressful conditions, which has resulted in the improved weight gain because of stronger anti-peroxidation capacity of tissues with higher retention of VE in muscles as recorded. The present findings were in accordance with that recorded by Monahan et al. (1992), Guidera et al. (1997), Mitsumoto et al. (1998) and Lauridsen et al. (1999), where VE supplementation of diets of meat producing animals effectively elevates muscle VE levels and lowers the susceptibility of muscle and ultimately products to lipid oxidation and the onset of flavour defects.

Apparently, dietary VE supplementation had no effect on immune cell populations in chicken. Our observations were not in agreement with that of previous studies by Erf et al. (1998). They reported VE supplementation in feed appeared to exert effect on the T-cell compartment, specifically CD4+ T cell. According to them, specific effects of dietary VE on $\mathrm{T}$ cell differentiation were for the most part not apparent in 2 week-old chickens but very apparent in 7-week-old chickens fed high levels of dietary VE. The less impact of supplementation in our study may be the age as we conducted study at 4 weeks of age. Scanty reports are available with respect to effect of VE on lymphocyte subpopulation. Further studies needs to be done to see the effect of VE supplementation on lymphocyte subpopulations. 
The ND titers were not significantly influenced at $14^{\text {th }}$ or $28^{\text {th }}$ day of measurement by VE supplementation. The antibody titer to IB was decreased in all groups except $10 \mathrm{mg} / \mathrm{kg}$ VE-PEG between two bleeding points. It is interesting that the degree of the decrease was much higher in the control group than in VE supplemented groups. On the other hand, the antibody titer to ND vaccination was increased in all groups from $14^{\text {th }}$ day to $28^{\text {th }}$ day post vaccination. It is worthwhile to note that the degree of the increase of antibody titer was much higher in VE supplemented as compared to that of the control group. It is postulated that VE supplementation might influence the antibody production upon antigen exposure and continuity of antibody response once the antibody formed. The reason for different antibody response trends between IB and ND vaccines could be the nature of antigen. Leshchinsky and Klasing (2001) found that the effect of VE supplementation on the humoral immune response depended on the nature of antigen. They noted a dose-dependent increase in antibody production in response to attenuated infectious bronchitis vaccine between 0 and $25 \mathrm{IU} / \mathrm{kg}$ of supplemented VE and antibody levels to sheep red blood cells were higher in $50 \mathrm{IU} / \mathrm{kg}$ VE compared to those supplemented with 0 or $200 \mathrm{IU} / \mathrm{kg}$ of VE, while antibody production in response to Brucella abortus antigens and live IBV vaccine were not influenced by VE supplementation in their study. We could not evaluate the exact effect of dietary VE levels on this immune parameter. Further research in large number of birds is necessary before drawing any conclusion.

\section{CONCLUSIONS}

The VE requirement as suggested by NRC (1994), $10 \mathrm{mg} / \mathrm{kg}$ feed, did not meet the requirements of the birds at different conditions and is not sufficient to maintain the storage stability of the meat and meat products. Also the inconsistencies in the results obtained by various workers for VE requirements differ, as the conditions in the environmental farm are altogether different than those in the commercial situation. Hence alternative indices to know the biological status of the VE in different tissues can be helpful to know the immunity as well as physiological status of the bird. Further researches need to be conducted in this direction. The present study recorded the beneficial effect of the supplementation of VE in the PEG-complex form at $50 \mathrm{mg} / \mathrm{kg}$ level to improve the keeping quality of meat and there was also impact on the growth performance which was equivalent to that provided by $200 \mathrm{mg} / \mathrm{kg}$ of $\mathrm{VE}$ as $\alpha$-tocopheryl acetate. 


\section{REFERENCES}

AOAC, 1990. Official Methods of Analysis, Association of Official Analytical Chemists. $15^{\text {th }}$ Edition. Arlington, VA

Davis W.C., Hamilton M.J., Park Y.H., Larsen R.A., Wyatt C.R., Okada K., 1990. Ruminant leukocyte differentiation molecules. MHC, differentiation antigens and cytokines in animals and birds. Monographs Anim. Immunol. 1, 47-70

DeVore V.R., Colnago G.L., Jensen L.S., Greene B.E., 1983. Thiobarbituric acid values and glutathione peroxidase activity in meat from chickens fed a Se supplemented diet. J. Food Sci. 48, 300-301

Dudin V.I., Dvinskaya L.M., 1984. Effect of ethoxyquin on metabolism of alpha tocopherol in tissues of broiler chickens. Sel'skokhoz. Zhiv. 3/75, 59-62

Erf G.F., Bottje W.G., Bersi T.K., Headrick M.D., Fritts C.A., 1998. Effects of dietary vitamin E on the immune system in broilers: Altered proportions of CD4 T cells in the thymus and spleen. Poultry Sci. 77, 529-537

Franchini A., Meluzzi A., Bertuzzi S., Giordani G., 1988. High doses of vitamin E in the broiler diets. Arch. Geflügelk. 52, 12-16

Frigg M., Prabucki A.L., Crippa P., 1990. Floor pen trial on the effect of dietary vitamin E on performance and oxidative stability of broiler meat. Zoot. Int. (December), pp. 22-30

Guidera J., Kerry J.P., Buckley D.J., Lynch P.B., Morrissey P.A., 1997. The effect of vitamin E supplementation on the quality of fresh and frozen lamb meat. Meat Sci. 45, 33-43

Guo Y., Tang Q., Yuan J., Jiang Z., 2001. Effects of supplementation with vitamin Eon the performance and the tissue peroxidation of broiler chicks and the stability of thigh meat against oxidative deterioration. Anim. Feed Sci. Tech. 89, 165-173

Haq A.U., Bailey C.A., Chinnah A., 1996. Effect of beta-carotene, carlthaxanthin,lutein, and vitamin E on neonatal immunity of chicks when supplemented in the broiler breeder diets. Poultry Sci. $75,1092-1097$

Jacobsen K., Engberg R.M., Andersen J.O., Jensen S.K., Lauridsen C., Sorensen P., Henckel P., Bertelsen G., Skibsted L.H., Jensen C., 1995. Supplementation of broiler diets with all-racalpha- or a mixture of natural source RRR-alpha-,gamma-,delta-tocopheryl acetate. 1. Effect on vitamin E status of broilers in vivo and at slaughter. Poultry Sci. 74, 1984-1994

Lauridsen C., Hojsgaard S., Sorensen M.T., 1999. Influence of dietary rapeseed oil, vitamin E and copper on the performance and the oxidative status of pigs. J. Anim. Sci. 77, 906-916

Leshchinsky T.V., Klasing K.C., 2001. Relationship between the level of dietary vitamin E and the immune response of broiler chickens. Poultry Sci. 80, 1590-1599

LG Chemicals Co. Report., 2000. A Brochure of Product Information. LG Life Sciences Ltd., Seoul (Korea)

Lohakare J.D., Hahn T.-W., Shim Y.H., Choi J.Y., Chae B.J., 2004. Effects of feeding methods (feed versus water) of vitamin $\mathrm{E}$ on growth performance and meat quality of broilers. Asian-Austr. J. Anim. Sci. 17, 1260-1265

Mazija H., Serman V., Mas N., Prukner-Radovicic E., 1992. Immune response as marker of needs for vitamins in chickens. 4. The influence of vitamin $\mathrm{E}$ on the immune response and development of immune system organs in chickens. Krmiva 34 (2), 77-81

McCorkle F.M., Glick B., 1980. The effect of ageing on immune competence in the chicken : antibody mediated immunity. Poultry Sci. 59, 669-672

McIlroy S.G., Goodall E.A., Rice D.A., McNulty M.S., Kennedy D.G., 1993. Improved performance in commercial broiler flocks with sub-clinical infectious bursaldisease when fed diets containing increased concentrations of vitamin E. Avian Pathol. 22, 81-94 
Mitsumoto M., Ozawa S., Mitsuhashi T., Koide K., 1998. Effect of dietary vitamin E supplementation for one week before slaughter on drip, color and lipid stability during display in Japanese black steer beef. Meat Sci. 49, 165-174

Monahan F.J., Gray J.I., Booren A. M., Miller E.R., Buckley D. J., Morrissey P.A., Gomaa E.A., 1992. Influence of dietary treatment on lipid and cholesterol oxidation in pork. J. Agr. Food Chem. 40, 1310-1315

Morrissey P.A., Sheehy P.J.A., Galvin K., Kerry J.P., Buckley D.J., 1998. Lipid stability in meat and meat products. Meat Sci. 49, S73-S86

National Research Council, 1994. Nutrient Requirements of Poultry. $9^{\text {th }}$ Edition. National Academy Press. Washington, DC

Norazlina M., Ima-Nirwana S., Khalid B.A.K., 1999. Effects of palm vitamin E, vitamin D and calcium supplementation on bone metabolism in vitamin $\mathrm{E}$ deficient rats. Medical J. Islamic Academy Sci. 12, 13-25

Rice D.A., Kennedy S., 1988. Vitamin E and free radical formation. In: W. Haresign, D.J.A. Cole (Editors). Recent Advances in Animal Nutrition. London, Butterworths, pp. 39-57

SAS Institute, 1985. SAS ${ }^{\circledR}$ User's Guide: Basics. SAS Institute Inc. Cary, NC

Scott M.L., Stoewsand G.S., 1961. A study of the ataxia of vitamin A and vitamin E deficiencies in the chick. Poultry Sci. 40, 1517-1523

Sheehy P.J.A., Morrissey P.A., Flynn A., 1991. Influence of dietary alpha-tocopherol on tocopherol concentrations in chick tissues. Brit. Poultry Sci. 32, 391-397

Sinnhubber R.O., Yu T.C., 1977. The 2-thiobarbituric acid reaction, an objective measure of the oxidative determination occurring in fats and oils. J. Jpn. Soc. Fish Sci. 26, 259-267

Soto-salanova M.F., Sell J.L., Mallarino E.G., Piquer F.J., Barker D.L., Palo P.E., Ewan R.C., 1993. Research note: Vitamin E status of turkey poults as influenced by different vitamin E sources, a bile salt and an antioxidant. Poultry Sci. 72, 1184-1188

Tengerdy R.P., Mathias M.M., Nockels C.F., 1984. Effect of vitamin E on immunity and disease resistance. Pages 118-122 In: K.N. Prasad (Editor). Vitamins, Nutrition and Cancer. Karger, Basel (Switzerland)

Xu H., Watkins B.A., Seifert M.F., 1994. Vitamin E status can alter bone histo-morphometry. J. Bone Miner. Res. 9, S249 


\section{VITAMIN E - POLYETHYLENE GLYCOL COMPLEX FOR BROILERS}

\section{STRESZCZENIE}

\section{Wpływ kompleksu witamina E - glikol polietylenowy na wzrost, jakość mięsa oraz odporność u kurcząt brojlerów}

W 6-tygodniowym doświadczeniu, przeprowadzonym na 330 brojlerach Ross rozpoczynając od 4-go dnia życia, badano wpływ dodatku kompleksu witamina E - glikol polietylowy (VE-PEC) na wyniki produkcyjne w warunkach przemysłowych. Kurczęta podzielono na 5 grup, stosując następujące dodatki VE do diet, $\mathrm{mg} / \mathrm{kg}$ : 1.0 (negatywna kontrola), 2. 200 octanu $\alpha$-tokoferolu, 3. 10 VE-PEG, 4. 20 VC-PEG, i 5. 50 VC-PEG.

Dodatek VE spowodował poprawę przyrostów m.c. kurcząt w grupach 2, 4 i 5 w porównaniu z 1 i 3, lecz nie wpłynął na pobranie i wykorzystanie paszy. Oporność kości została zwiększona we wszystkich grupach otrzymujących dodatek $\mathrm{VE}$, a istotnie większą $\mathrm{P}<0,05$ zawartość $\mathrm{P}$ w kościach stwierdzono u kurcząt z grupy 5 (50 mg VE-PEG). Wydajność rzeźna, zawartość mięśnia piersiowego i thuszczu brzusznego oraz kolor mięsa nie różniły się między grupami. Poziom VE w surowicy krwi i jej stężenie w mięśniach były dodatnio skorelowane z jej ilością $\mathrm{w}$ diecie. Poziom aktywnych związków kwasu tiobarbiturowego $(\mathrm{mg} / \mathrm{kg})$ w mięsie wskazuje również na zapobiegawczą rolę VC przeciw jełczeniu. Liczba komórek cytotoksycznych (CD8) i B-limfocytów była większa u kurcząt z grupy 5 niż z pozostałych grup. Dodatek VE nie miał natomiast wpływu na zapalenie oskrzeli i tworzenie przeciwciał przeciw chorobie Newcastle.

$\mathrm{W}$ podsumowaniu stwierdzono, że podawanie dużych dawek $\mathrm{VC}$, tak w formie octanu $\alpha$-tokoferolu jak i kompleksu VE-PEG, wpływa dodatnio na wzrost, odporność oraz poprawia jakość mięsa kurcząt. 